\title{
PENGARUH SPIRITUAL QUOTIENT TERHADAP KATANGGUHAN MASYARAKAT SEKOLAH
}

\author{
Oleh: \\ Muhasim \& Zulfikar Muhammad \\ Sekolah Tinggi Ilmu Kesehatan Kepanjen, Indonesia \\ abu.aufar11.12@gmail.com \& zoemoeh17@gmail.com
}

\begin{abstract}
:
Disasters are cannot be separated from our daily lives. The threat of disaster at any time lurks the Indonesian nation. Therefore, Indonesian people must be ready and resilient in facing disasters so that they can minimize fatalities. Various things are done, all components are expected to work together to achieve a disaster resilient society. BNPB (The National Disaster Mitigation Agency) creates various programs for disaster preparedness to minimize fatalities. Spiritual Quotien (spiritual intelligence) as an element in religion which has a strategic role in disaster preparedness. The purpose of this study was to determine the effect of spiritual quotient level on society resilience in the school environment. This research method uses a correlational cross-sectional approach which measuring the variables at one particular moment. The population in this study was SMA Muhammadiyah I Kota Malang. The sample used was 75 people. The sampling technique used purposive sampling. The group will take measurements related to the level of spiritual quotient and society resilience. Furthermore, data analysis will be carried out to see the effect of the spiritual quotient level on society resilience based on the significance with a different test analysis using the Wilcoxon statistical test with a significance level of 95\%. The results showed a significant value of 0.004 which means that there is a significant effect of spiritual quotient on society resilience at SMA Muhammadiyah 1 Kota Malang. This research is expected to provide input on the importance of a spiritual quotient in increasing the resilience of school societies in disaster-prone area.
\end{abstract}

Keyword: Spiritual Quotient, Ketangguhan Masyarakat, Sekolah

\section{A. Pendahuluan}

Spiritual Quotien atau kecerdasan spiritual belum Nampak jelas pengaruhnya dalam ketangguhan masyarakat. Hal ini bisa dilihat dari buku Peraturan Kepala Badan Nasional Penanggulangan Bencana yang belum menampilkan secara eksplisit kecerdasan spiritual dalam ketangguhan masyarakat baik dalam persiapan, saat bencana maupun 
pasca bencana.

Spiritual dalam kehidupan manusia sangatlah penting. Bahkan hal ini dapat dilihat dari buku "Rahasia Sukses membangun Kecerdasan emosional dan Spiritual", Spritual quotient adalah yang paling utama dalam kehidupan manusia. Manusia tidak bisa terpisahkan dari spiritual. Dengan kecerdasan spiritual manusia diharapkan memiliki tujuan hidup yang benar, memliki pegangan hidup dalam menjalani kehidupan ini.

Bencana di Indonesia sudah sering terjadi, bencana gempa dan tsunami Aceh (2004), gempa Yogyakarta (2006), Tasikmalaya (2009), Sumatra Barat (2010), gempa dan tsunami Mentawai (2010), tanah longsor Wassior di Papua Barat (2010) dan letusan Gunung Merapi Yogyakarta (2010) yang membawa korban ratusan jiwa dan ratusan triliun rupiah dalam nilai ekonomi. Letusan Gunung Merapi yang tak kunjung reda, makin mempertegas predikat NKRI sebagai negara sabuk api. Indonesia harus siap siaga apabila sewaktu-waktu terjadi bencana.

Badan Nasional Penanggulangan Bencana (BNPB) adalah satu badan yang menangani terkait kebencanaan di Indonesia. Berbagai usaha dilakukan oleh BNPB untuk terus berusaha menjadikan Indonesia menjadi negara yang Tangguh dalam menghadapi benacana. Penelitian, pelatihan, Pendidikan dilakukan agar bangsa Indonesia menjadi Tangguh bencana.

Orang yang memiliki kecerddasan spiritual yang baik akan mampu memebrikan hal-hal yang positif pada suatu kejadian. Spiritual quotient atau kecerdasan spiritual adalah kecerdasan yang menjadikan orang menjadi orang yang memiliki pandangan hidup yang jauh. ia memiliki prinsip dan visi yang kuat dan mampu memaknai suatu kejadian dengan baik dan mampu bertahan dalam kesulitan dan kesengsaraan. ${ }^{1}$

Dengan kecerdasan spiritual yang dimiliki seseorang diharapakan ia memiliki kepekaan terhadap hal yang belum terjadi. Memiliki kemampuan dalam menghadapai suatu cobaan. Serta mampu memaknai suatu kejadian bencana dengan baik dan ia mampu bangkit dalam menghadapi kehidupan ini setelah terjadi bencana ${ }^{2}$.

Dari apa yang telah dijelaskan peneliti ingin meneliti bagaimana pengaruh spiritual quotient terhadap ketangguhan masyarakat sekolah. Dengan harapan semoga penelitian ini menjadi masukan bagi pihak terkait sehingga bisa dijadikan pertimbangkan dalam Menyusun program untuk ketangguhan masyarakat sekolah.

1 Ani Muttaqiyatun, Pengaruh kecerdasan intelektual, Kecerdasan Emosional dan kecerdasan spiritual terhadap kinerja dosen, jurnal e-biling, 401.

${ }^{2}$ Ibid, 401.

2

JURNAL LISAN AL-HAL 


\section{B. Konsep Spiritual Quotient}

Zohar \& Marshal dalam menjelaskan kecerdasan spiritual sebagai kecerdasan untuk menghadapi dan memecahkan persoalan makna dan nilai yaitu kecerdasan untuk menempatkan perilaku hidup kita dalam makna yang lebih luas dan kaya, kecerdasan untuk menilai bahwa tindakan atau jalan hidup seorang akan lebih bermakna dibandingkan yang lain.

Zohar \& Marshall memberikan arti yang berbeda mengenai spiritualitas dan religiusitas, bahwa spiritualitas tidak berhubungan dengan religiusitas. Religiusitas terkait agama (religion) yang merupakan dasar-dasar dengan kehidupan yang membuat hidup individu menjadi teratur, sedangkan spiritualitas merupakan usaha individu untuk mencapai tingkat mental tertentu di mana pada kondisi tersebut manusia berusaha dengan keras untuk menyatu dengan Tuhannya, menyatu dengan alam semesta dan menyatu dengan energi di sekitarnya ${ }^{3}$.

spiritualitas merupakan usaha individu untuk mencapai tingkat mental tertentu di mana paSpiritual Quotien atau kecerdasan spiritual merupakan kecerdasan dalam memberikan arti hidup sehingga seseorang mampu membuat tujuan yang mulia ${ }^{4}$. Orang yang sudah memiliki spritiual quotient yang baik maka ia mampu menemukan makna dalam setiap kejadian yang terjadi. Ia berkeyakinan tidak ada kejadian di dunia ini kecuali semua atas kehendak Allah tuhan yang maha esa.

Ari ginanjar agustian dalam mengatakan bahwa spiritual quotient adalah aplikasi dari rukun iman dalam islam. Ia mampu mengaplikasikan bahwa setiap kejadian yang ada adalah bentuk beribadah keada Allah SWT. Sholat dzikir bahkan bekerja bergaul merupkan ibadah kepada Allah SWT $^{5}$

Orang dengan spiritual quotien baik seharusnya memiliki visi yang baik dalam menghadapai kehidupan ini. Ia mampu menyikapi setiap kejadian dengan baik. Ketika ia mendapatkan nikmat pandai untuk bersyukur dan ketika ditimpa musibah ia pandai bersabar. Karena dengan konsep iman keyainan yang tinggi akan Allah dan takdir bahwa baik buruk

3 Wiwid, Widyastuti, Pengaruh kecerdasan Emosional Kecerdasan Spiritual dan Budaya berorganisai.

4 Peter garlanse \& A. Noya, Pengaruh Kecerdasan Spiritual terhadap terhadap pengelolaan keuangan pribadi, Vol.11, (Bandung: Jurnal Manajemen Marantha, 2012), 171.

5 Muhasim, Pengaruh Spiritual Quotient orang tua terhadap Prestasi akademik mahasiswa stikes kepanjen, vol 3 (Jombang: Jurnal Akademika,2018), 3. 
itu dari allah ia menerimanya dengan baik dan menyikapinya sesuai dengan tuntunan dari Allah SWT. Hal ini sejalan dengan firman Allah SWT:

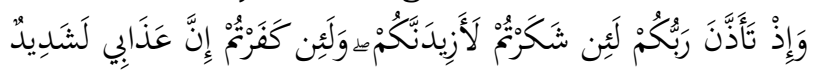

"Dan (ingatlah juga), tatkala Tuhanmu memaklumkan; "Sesungguhnya jika kamu bersyukur, pasti Kami akan menambah (nikmat) kepadamu, dan jika kamu mengingkari (nikmat-Ku), maka sesungguhnya azab-Ku sangat pedih". (Q.S. Ibrohim ; 7)

Dan Nabi Muhammad SAW Bersabda ;

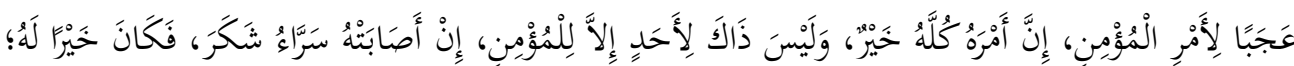

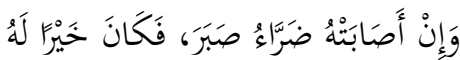

"Sungguh menakjubkan urusan orang beriman. Seluruh urusannya merupakan kebaikan, dan ini tidak dimiliki kecuali oleh orang beriman. Jika mendapatkan kenikmatan, dia bersyukur, dan itu baik baginya; jika tertimpa musibah, dia bersabar, dan itu baik baginya." (HR. Muslim no. 7692)

Berhubungan dengan bencana, orang dengan spiritual quotient yang baik, maka akan memiliki kepedulian yang tinggi juga terhadap ketangguhan masyarakat. Ia akan belajar untuk memahami tentang alam ini. Bagaiamana alam ini bisa terus lestari sebagaimana tugasnya sebagai kholifah di atas muka bumi ini. Ia akan berusaha untuk menjaga bumi ini dari terjadinya kerusakan, akan berusaha untuk tidak menjadi penyebab terjadi bencana. Karena allah SWT menjelaskan bahwa kerusakan di muka bumi ini akibat perilaku manusia. Sebagaimana firman Allah SWT:

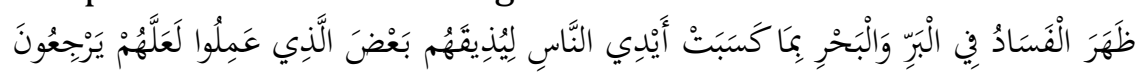

"Telah nampak kerusakan di darat dan di laut disebabkan karena perbuatan tangan manusi, supay Allah merasakan kepada mereka sebahagian dari (akibat) perbuatan mereka, agar mereka kembali (ke jalan yang benar)". (Q.S. Ar-rum 41)

Ketika terjadi bencana, orang yang memiliki spiritual quotient yang baik juga akan memiliki pemahaman apa yang seharusnya ia lakukan. Tahu bagaiamana supaya di bisa selamat dan orang lain pun selamat dengan mengikuti alur evakuai penyelamatan yang telah ditentukan dalam pendidikan dan simulasi bencana.

Pasca terjadinya bencana orang yang memiliki spiritual quotient juga bisa dengan mudah untuk rehabilitasi diri. Dengan kekuatan imannya kepada Allah SWT ia sadar bahwa bencana yang terjadi merupakan takdir dari Allah SWT. Begitupun ia mengetahui bahwa setiap kejadian yang 
terjadi tidak sia-sia dan memiliki hikmah. Ia akan mencari hikmah apa yang terkadung di dalamnya. Sebagaimana firman Allah SWT:

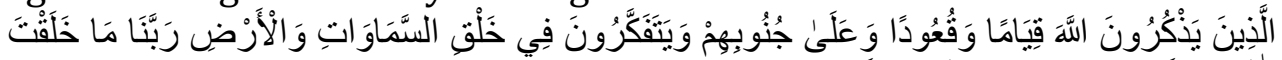

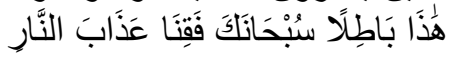

"(yaitu) orang-orang yang mengingat Allah sambil berdiri atau duduk atau dalam keadan berbaring dan mereka memikirkan tentang penciptaan langit dan bumi (seraya berkata): "Ya Tuhan kami, tiadalah Engkau menciptakan ini dengan sia-sia, Maha Suci Engkau, maka peliharalah kami dari siksa neraka” (Q.S. Ali 'Imron; 191).

Seharusnya orang yang memiliki spiritual quotient baik pra bencana, saat bencana dan pasca bencana ia mampu untuk menyesuaikan dengan prosedur ketangguhan masyarakat dalam menghadapi bencana. Karena, orang yang spiritual quotientnya baik ia tidak acuh dengan teori ahli dan hanya pasrah diri terhadap apa yang terjadi. Kesabaran yang ia miliki bukan dalam arti kepasrahan atas apa yang akan terjadi, yang sedang terjadi dan yang telah terjadi, tetapi kesabaran dalam menyiapkan kesiapsiagaan bencana, sabar dalam menghadapi bencana untuk menyelamatkan diri sendiri dan orang lain, serta sabar dalam kembali bangkit setelah terjadinya bencana

\section{Konsep Ketangguhan Masyarakat Sekolah}

Bencana menurut (Undang-Undang Republik Indonesia Nomor 24 Tahun 2007 Tentang Penanggulangan Bencana, 2007) adalah peristiwa atau rangkaian peristiwa yang mengancam dan mengganggu kehidupan dan penghidupan masyarakat yang baik disebabkan, alam oleh faktor dan/atau faktor nonalam maupun faktor manusia sehingga mengakibatkan timbulnya korban jiwa manusia, kerusakan lingkungan, kerugian harta benda, dan dampak psikologis ${ }^{6}$.

Undang-undang ini memeberikan pemahaman bahawa kejadian bencana akan menghasilkan pada terganggunya kehidupan manusia dan penghidupan manusia. Sedang faktor yang menyebabkan terjadinya bencana ada dua, pertama bencana karena faktor alam, dan manusia. Bencana yang dikarenakan oleh faktor alam seperti gunung meletus, gempa bumi, Tsunami. Sedang bencana yang diakibatkan oleh manusia seperti buang sampah yang mengakibatkan banjur, penggundulan hutan yang mengakibatkan longsor dan lain-lain.

Dalam Rencana Nasional Penanggulangan Bencana 2010-2014

${ }^{6}$ UU, Undang-Undnag no 24 Tahun 2007 Tentang Penanggulangan Bencana, (Jakarta, Sekretariat Negara: 2007) hal. 2 
telah direncanakan adanya implementasi kesiap siagaan bencana disekolah/madrasah. Hal ini penting, mengingat banyak sekolah/ madrasah yang berada di wilayah rawan bencana gempa bumi dan tsunami. Sekolah/madrasah pada jam-jam pelajaran merupakan tempat berkumpulnya anak didik yang tentunya mempunyai kerentanan tinggi. Apabila tidak dilakukan upaya pengurangan risiko bencana, maka sekolah/madrasah menjadi tempat yang berisiko tinggi. Secara kuantitatif yakni sebanyak 75\% sekolah di Indonesia berada pada risiko sedang hingga tinggi dari bencana. Kemdikbud mendata sampai akhir tahun 2011 sebanyak 194.844 ruang kelas rusak berat di SD/SDLB dan SMP/SMPLB. Tahun 2011 telah terealisasi rehabilitasi sebanyak 21.500 ruang kelas, sisanya sebanyak 173.344 ruang kelas rusak berat akan direhabilitasi pada tahun anggaran 2012. Sementara data Kemenag menunjukkan dari 208.214 ruang kelas MI dan MTs, sebanyak 13.247 ruang kelas rusak berat dan 51.036 ruang kelas rusak ringan. Perka ini mengatur pedoman desa tangguh bencana7.

Permasalahan ini lah yang melatar belakangi lahrnya Perka BNPB Nomor 4 tahun 2012 tentang Pedoman Penerapan Sekolah/Madrasah Aman dari Bencana. Diharapkan dengan adanya perka ini banyak sekolah yang sadar untuk pendidikan kesiapsiagaan bencana, sehingga bisa meminimalisir terjadi korban jiwa saat bencana.

Sekolah/madrasah aman dari bencana adalah sekolah/ madrasah yang menerapkan standar sarana dan prasarana serta budaya yang mampu melindungi warga sekolah dan lingkungan di sekitarnya dari bahaya bencana. Penerapan sekolah/madrasah aman dari bencana terutama didasarkan pada pertimbangan sebagai berikut:

1. Mengurangi gangguan terhadap kegiatan pendidikan, sehingga memberikan jaminan kesehatan, keselamatan, kelayakan termasuk bagi anak berkebutuhan khusus, kenyamanan dan keamanan di sekolah dan madrasah setiap saat;

2. Tempat belajar yang lebih aman memungkinkan identifikasi dan dukungan terhadap bantuan kemanusiaan lainnya untuk anak dalam situasi darurat sampai pemulihan pasca bencana;

3. Dapat dijadikan pusat kegiatan masyarakat dan merupakan sarana sosial yang sangat penting dalam memerangi kemiskinan, buta huruf dan gangguan kesehatan;

7 Perka, BNPB,2012, Pedoman Penerapan Sekolah/Madrasah Aman dari Bencana, (Jakarta;BNPB, 2012). 2. 
4. Dapat menjadi pusat kegiatan masyarakat dalam mengkoordinasi tanggap dan pemulihan setelah terjadi bencana;

5. Dapat menjadi rumah darurat untuk melindungi bukan saja populasi sekolah/madrasah tapi juga komunitas dimana sekolah itu berada ${ }^{8}$.

\section{Metode Penelitian}

Metode penelitian ini menggunakan korelasional dengan pendekatan cross-sectional yaitu melakukan pengukuran variabel pada satu saat tertentu. Variable dependen dalam penelitian ini adalah Spiritual Quotien masyarakat SMA Muhammadiyah 1 Kota Malang. Variable independen adalah Ketangguhan Masyarakat SMA Muhammadiyah 1 Kota Malang. Penelitian ini dilaksanakan pada bulan agustus 2020. Tempat penelitian SMA Muhammadiyah 1 Kota Malang

Populasi pada penelitian ini adalah SMA Muhammadiyah I Kota Malang. Sampel yang digunakan sebanyak 75 orang. Teknik sampling menggunakan purposive sampling. Kelompok dilakukan pengukuran terkait dengan tingkat Spiritual Quotient dan ketangguhan masyarakat Sekolah. Selanjutnya akan dilakukan analisis data untuk melihat pengaruh dari tingkat Spiritual Quotient terhadap ketangguhan masyarakat berdasarkan signifikansinya dengan analisis uji beda dengan menggunakan uji statistik Wilcoxon dengan taraf signifikansi 95\%

\section{E. Hasil Penelitian}

SMA Muhammadiyah 1 Kota malang adalah sekollah di bawah yayasan PP Muhammadiyah. Beralamatkan di Jl. Brigadir Jenderal Slamet riyadi No. 134 Klojen, Kota Malang. Sekolah ini memiliki Visi Islami, Berkarakter, Unggul, Kreatif, Ramah Anak. Sekolah yang dipimpin oleh ibu Dra. Umi Mafrukhah ini juga perhatian terhadap kesiaosiagaan bencana ini terbukti dengan diadakannya simulasi bencana pada tahun 2018.

Setelah diberikan kuesioner didapatkan hasil peneleitian sebagaimana berikut: sebanyak 75 Responden mengisi kuesioner yang dilakukan secara online melalui google form dengan karakteristik responden sebagaimana berikut. Dari jenis kelamin responden sebanyak 35 Orang berjenis kelamin laki-laki, dan sebanyak 40 orang berjenis kelamin Perempuan, sebagaimana berikut:

${ }^{8}$ Ibid, 3.

9 Sugiyono. (2013). Metode Penelitian Kuantitatif, Kualitatif dan R\&D. Bandung: Alfabeta.CV. 206. 
Tabel 3.1 karakteristi responden berdasarkan jenis kelamin

\begin{tabular}{llll}
\hline No & Jenis Kelamin & Jumlah & Persen \\
\hline 1 & Laki-laki & 35 Orang & $46.7 \%$ \\
\hline 2 & Perempuan & 40 Orang & $53.3 \%$ \\
\hline & Jumlah & 75 Orang & $100 \%$ \\
\hline
\end{tabular}

Karakteristik responden berdasarkan status di SMA Muhammadiyah 1 Kota Malang adalah sebagaimana berikut. Sebanyak 5 orang ada lah pimpinan, dan sebanyak 17 orang adalah guru, karyawan atau tenaga kependidikan di SMA Muhammadiyah 1 Kota Malang. Sedangkan sebanyak 54 adalah siswa SMA Muhammadiyah 1 Kota Malang. Karakteristik responden berdasarkan status di SMA Muhammadiyah 1 Kota Malang sebagaiaman dalam table berikut:

Table 3.2 Karakteristik responden berdasarkan status

\begin{tabular}{llll}
\hline No & Status & Jumlah & Persen \\
\hline 1 & Pimpinan & 5 Orang & $6.7 \%$ \\
\hline 2 & Guru dan Karyawan & 17 Orang & $21.3 \%$ \\
\hline 3 & Siswa & 54 Orang & $72 \%$ \\
\hline & Jumlah & 75 Orang & $100 \%$ \\
\hline
\end{tabular}

Selanjutnya karakteristik responden berdasarkan usia sebagaimana berikut, responden dengan rentang usia antara 15-25 Tahun sebanyak : 54 orang, rentang usia antara 26-35 Tahun sebanyak 9 orang, rentang usia antara 36-45 Tahun sebnayak 3 orang, rentang usia antara 46-55 Tahun sebanyak 4 orang dan rentang 56-65 Tahun sebanyak 5 orang. Data karakteristik responden berdasarkan usia sebagaimana table berikut:

Tabel 3.3 karakteristik responden berdasarkan Usia

\begin{tabular}{|c|c|c|c|}
\hline & Usia & Jumlah & Persen \\
\hline 1 & 15-25 Tahun & 54 Orang & $72 \%$ \\
\hline 2 & 26-35 Tahun & 9 Orang & $12 \%$ \\
\hline 3 & 36-45 Tahun & 3 Orang & $4 \%$ \\
\hline 4 & 46-55 Tahun & 4 Orang & $5.3 \%$ \\
\hline & 56-65 Tahun & 5 Orang & $6.7 \%$ \\
\hline \multicolumn{2}{|c|}{ Total } & 75 Orang & $100 \%$ \\
\hline
\end{tabular}


Hasil penelitian terkait dengan pengukuran pengaruh spiritual quotient terhadap ketangguhan masyarakat sekolah SMA Muhammadiyah 1 Kota Malang setelah dilakukan tabulasi data dan analisis data menggunakan wilcoxon ditemukan hasil sebagaimana berikut:

\begin{tabular}{|l|l|}
\begin{tabular}{|l|l|}
\hline \multicolumn{2}{|c|}{ Test Statistics(b) } \\
\hline Z & Kesiapsiag aan -SQ \\
Asymp. Sig. & $-2,799(\mathrm{a})$ \\
(2-tailed) &, 005 \\
\hline
\end{tabular}
\end{tabular}

a Based on positive ranks.

b Wilcoxon Signed Ranks Test

\section{F. Pembahasan}

Menurut Dhanah Zohar Spiritual Quotient mempengaruhi terhadap Integensi Quotient dan Emotional Quotien. Yang artinya orang yang memiliki kecerdasan spiritual baik maka intelegent dan emotional quotient juga akan baik. Orang dengan tingkat spiritual quotient baik maka ia mampu berfikir dengan baik juga mampu mengendalikan emosi dengan baik. Serta ia mampu memberikan makna terhadap kejadian yang terjadi pada dirinya.

Menurut Ari Ginanjar Agustian dalam mengatakan bahwa spiritual quotient adalah aplikasi dari rukun iman. Rukun iman terdapat 6 rukun yakni iman kepada Allah, Iman kepada malaikat, iman kepada kitab-kitab Allah, iman kepada rosul-rosul allah, iman kepada hari akhir dan iman kepada qodlo dan qodar Allah SWT ${ }^{10}$.

Hasil penelitian tentang spiritual quotien di SMA Muhammadiyah 1 Kota malang menunjukkan masyarakat sekolah SMA Muhammadiyah 1 Kota Malang memiliki SQ yang baik. Hal ini dikarenakan dengan banyaknya muatan lokal yang berbasis agama, sehingga memberikan pemahaman yang lebih kepada siswa dalam memahami agama sehingga menumbah kecerdasan spiritual yang baik.

Hasil penelitian tentang ketangguhan masyarakat sekolah menunjukkan hal ini sesuai dnegan hasil penelitian Zulfikar Muhammad tentang pengaruh simulasi bencana terhadap ketangguhan masyarakat. Bahwa SMA Muhammadiyah 1 Kota melang telah mengadakan pelatihan

${ }^{10}$ Muhasim,2018. Pengaruh Spiritual Quotient ornag tua terhadap prestasi Akademik Mahasiswa STIKes Kepanjen, Jurnal dinamika, hal 3 
sekolah Tangguh bencana pada tahun 2018 yang bekerjasama dengan MDMC Muhammadiyah. Maka kiranya sekolah-sekolah lain dan madrasah bisa mengadakan kegiatan serupa untuk meningkatkan ketangguhan mmenghadapi bencana.

Sedang pengaruh spiritual quotient terhadap ketangguhan masyaraka menunjukan pengaruh yang signifikan. Hal ini sesuai dengan teori bahwa Ketika spiritual quotient baik maka intelegent dan emotional quotient juga baik. Intelegen adalah pengetahuan siswa tentang kesiapsiagaan bencana dan emotional quotient lebih mengarah bagaiamana bersikap pada saat pra-bencana saat bencana dan pascabencana.

\section{G. Simpulan}

Kesimpulan dari penelitian ini adalah, Terdapat pengaruh yang signifikan spiritual quotient terhadap ketangguhan masyarakat sekolah SMA Muhammadiyah 1 Kota Malang. Artinya spiritual quotient memeliki pengaruh yang siginifikan untuk mempengaruhi ketangguhan masyarakat sekolah. Peneliti berharap penlitian bisa menjadi acuan bahwa program SQ bisa diadakan untuk meningkatkan ketangguhan masyarakat sekolah dan masyarakat pada umumnya. Peneliti memebri saran untuk peneliti selanjutnya untuk mengembangkan penelitian ini pada komunitas yang lebih besar sehingga bisa memberikan gambaran yang lebih jelas terkait pengaruh spiritual quotient terhadap ketangguhan masyarakat.

\section{DAFTAR PUSTAKA}

Ajian, S. E. K., Tnopedagogi, A. N. E., Suarmika, P. E., \& Utama, E. G. Pendidikan Mitigasi Bencana Di Sekolah Dasar. Jurnal Pendidikan Dasar Indonesia, 2(September), 2017.

BNPB, P. Peraturan Kepala Badan Nasional Penanggulangan Bencana Nomor 1 Tahun 2012. BNPB, 66, 2012.

Muhasim, M. Pengaruh Spiritual Quotient Orang Tua Terhadap Prestasi Akademik Mahasiswa STIKES Kepanjen. Dinamika, 3(2), 2018.

Muttaqiyathun, A. Pengaruh kecerdasan emosional, kecerdasan intelektual dan kecerdasan spiritual terhadap kinerja dosen. E Biling, 2009.

Peter Garlans, S., \& Noya, A. Pengaruh Kecerdasan Spiritual Terhadap Pengelolaan Keuangan Pribadi. Jurnal Manajemen, 11(2), 2012.

Sugiyono. Metode Penelitian Kuantitatif dan R\&D. Bandung: Alfabeta. CV.

10 JURNAL LISAN AL-HAL 
2013.

Undang-Undang Republik Indonesia Nomor 24 Tahun 2007 Tentang Penanggulangan Bencana, 136 Lembaran Negara Republik Indonesia 232007.

Widyastuti, W., \& Ludigdo, U. Pengaruh Kecerdasan Emosional Kecerdasan Spiritual Dan Budaya Organisasi Terhadap Perilaku Etis Auditor Pada KAP. Jurnal Akuntansi Multiparadigma, 1, 2010. 
"Pengaruh Spiritual Quotient"

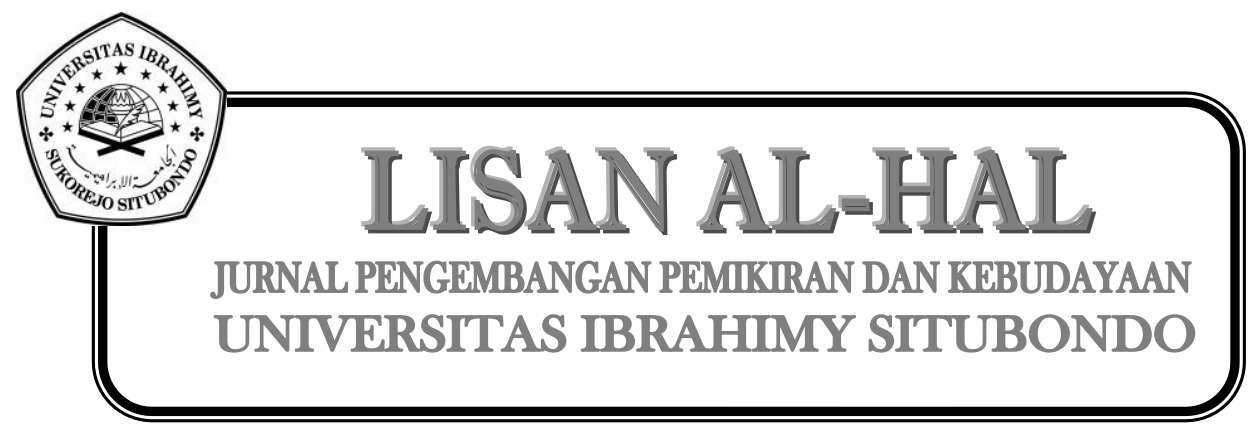

12 JURNAL LISAN AL-HAL 